\title{
A KNOWLEDGe Management METHODOLOGICAL VIEW TO IMPROVE Virtual Product DeVelopment
}

\author{
Dragoi, G.; Rosu, S.M.; Guran, M.; Cotet, C.E. \& Rosu, L.
}

Abstract: The knowledge management (KM) has received attention from designers responsible for the product development process because many of the design activities require a creative thought and is highly dependent on individual's knowledge. Furthermore, the product development process deals with a large amount of knowledge which makes the process more critical. Therefore, this work analyses the state of the art of the knowledge management and it proposes a methodological model used in the CESICED platform, based on the occurrence of types of conversions of the knowledge to be used during the product development process.

Key words: knowledge management, collaborative systems, virtual product, virtual enterprise
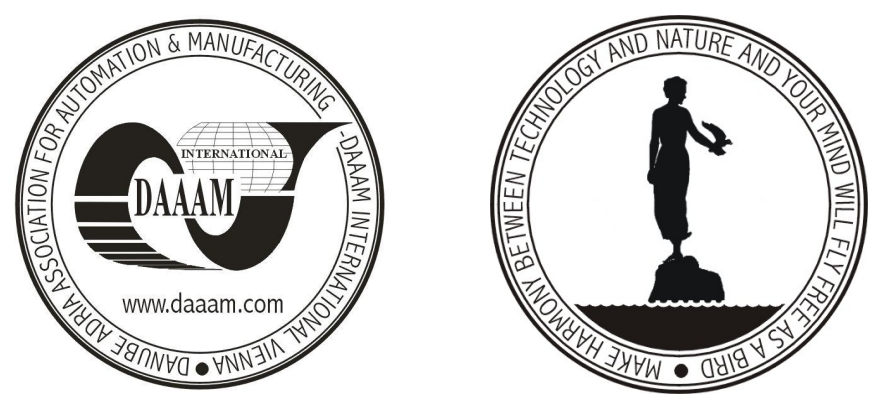

Authors' data: Dr. eng. Dragoi, G[eorge]*; Eng. Rosu, S[ebastian] M[arius]*; Dr. eng. Guran, M[arius]*; Dr. eng. Cotet, C[ostel] E[mil]*; Eng. Rosu, L[uminita]**, * University POLITEHNICA of Bucharest, Splaiul Independentei 313, sector 6, Bucharest, Romania, ** Grup ROMET SA Buzau, GRUP ROMET SA, Sos. Brailei no.15, 5100, Buzau, Romania, gdragoi@mix.mmi.pub.ro, sebastianrosu@stsnet.ro, mguran@mix.mmi.pub.ro,costel@mix.mmi.pub.ro,luminita@romet.ro

This Publication has to be referred as: Dragoi, G.; Rosu, S.M.; Guran, M.; Cotet, C.E. \& Rosu, L. (2007). A Knowledge Management Methodological View to Improve Virtual Product Development, Chapter 19 in DAAAM International Scientific Book 2007, B. Katalinic (Ed.), Published by DAAAM International, ISBN 3-901509-60-7, ISSN 1726-9687, Vienna, Austria

DOI: $10.2507 /$ daaam.scibook.2007.19 